\title{
A provisional guide to German military topographic map series of Ottoman Asia in the First World War
}

\author{
Imre Josef Demhardt \\ Department of History, University of Texas at Arlington, Arlington, USA - demhardt@uta.edu
}

\begin{abstract}
In acknowledgment that no war can be fought without maps, German military cartography between 1915 and 1918 gradually extended its cartographic involvement in the Ottoman theaters of Sinai, Mesopotamia and Palestine. By the end of the Great War, six topographical map series had been specially produced: Operationskarte in 1:800,000, Karte des türkisch-ägyptischen Grenzgebietes in 1:250,000, Karte von Mesopotamien (und Syrien) in 1:400,000, Karte von Nordbabylonien in 1:200,000, and Karte von Palästina in three scales 1:100,000, 1:50,000, and 1:25,000. The paper makes the first attempt on a carto-bibliographical appraisal of these map series.
\end{abstract}

Keywords: First World War, German military cartography, Sinai, Mesopotamia, Palestine

\section{Strategical background to German wartime cartography of Ottoman Asia}

When the Ottoman Empire agreed to join the Central Powers on 3.8.1914 (at first secretly), German hopes were that the addition of about 300,000 soldiers, in whose armies numerous German staff officers already served at the highest command posts, would, first, pull significant Entente forces away from the European fronts, and second, offer Germany an allied base to directly attack the British Empire, which was barely tangible in Central Europe. For that the Suez Canals, an Achilles tendon of the British Empire, seemed to be a low hanging fruit. Beyond that waterway lays Egypt, which centuries long Ottoman dependency de facto had annexed in 1882, and Constantinople longed to take back. Further strategic options were opening fronts against the Entente in the oil-rich Persian Gulf (Britain) and Caucasus (Russia) (Reichsarchiv 1933: 164). At the same time, however, the Ottoman Empire proved to be a burden for the Central Powers: a poorly developed backward economy under an inept administration with a military that not yet had recovered from the humiliating defeat in the Balkan War of 1912.

The anticipated combat areas were all in remote corners of the Empire: Sinai, Arabia, Persian Gulf, and Eastern Anatolia. All of which lay between 1,600 and 2,400 km away from Constantinople, with rugged desert or mountainous terrains with unruly inhabitants, barely connected to the capital by incomplete railways, in between. As it would turn out, the rail-line gaps through the southern Anatolian mountain ranges of Taurus and Amanus [= Nur] held up the deployment of troops and materials to Mesopotamia, Palestine, and Arabia for weeks if not months (Reichsarchiv 1933: 165-166). The damage caused by these delays easily equaled the harm several battle-hardened enemy divisions could inflict.

Against this background, the German Supreme Command intended to give the Ottoman Empire time to deploy in Palestine and Eastern Anatolia under the guise of the armed neutrality declared on August 3. In the face of the Russian summer attack on the German Empire and Austria-Hungary, however, it was pressing in September for these strikes (see Table 1). After the naval war against Russia opened in the Black Sea at the end of October, the Ottomans and Russians in late autumn got caught up in what evolved into a for years back and forth shifting front in the mountainous terrain of Eastern Anatolia. After early defeats the Ottomans had to fight deep into their own turf, taking a heavy toll on soldiers, material, and the other Asian fronts (Reichsarchiv 1933: 169-171). The Anatolian front and its temporary spread into Ottoman-Russian-British fighting in western Persia triggered only a few German maps but no map series, this introduction to German topographic map series on the Ottoman Empire will not get into that story.

The over the summer and autumn 1915 delayed British counterattack in the Sinai and slow progress in Mesopotamia can be attributed to the opening of a

\footnotetext{
${ }^{1}$ This paper is an introduction to the strategic settings of German war cartography in Ottoman Asia and a carto-bibliographical guide to pertaining map series, whose sheets and editions hitherto lack a comprehensive accounting. More detailed studies of the design and content of these map series are planned for future papers.
} 
temporary new front: To capture Constantinople, which likely would result in Ottoman surrender, the British and French on 25.4.1915 landed an invading army on the Gallipoli peninsula north of the Dardanelles Strait. Undoubtedly, the ensuing massive and brutal entrenched battle for Gallipoli represents the most prominent of all the Ottoman theaters of war, but no German original surveys took place during the eight months of the German campaign. Here German map support was restricted to reprinting existing Ottoman or enemy maps. Therefore, it suffices to note that the attempts to conquer the well-defended peninsula failed and on 9.1.1916 the last attackers evacuated the peninsula (Reichsarchiv 1933: 177-191). From a strategic point of view this may be viewed as a flawed Ottoman victory, mainly because of the ultimate withdrawal of the Entente. While the Central Powers were noticeably relieved for months on European fronts in 1915, the Ottomans, on the other hand, had to pull armies and resources from other fronts to defend the capital and maintain a sizeable force at the Dardanelles for the remainder of the war.

When Bulgaria entered the war on 14.10.1915 as ally of the Central Powers it provided the previously missing land connection of Germany and Austria-Hungary with the Ottoman Empire. It was now possible to send supplies and auxiliary troops to Constantinople to assist the Ottomans (Reichsarchiv 1933: 192-193). On 17.1.1916, the first direct train from Berlin arrived in Constantinople. A week before, with the retreat of the Entente from Gallipoli, the immediate threat to the Ottoman capital was averted (Reichsarchiv 1936: 603).

In June 1916, the Arab Revolt broke out in the Hedjaz in western Arabia, cutting off more than 10,000 Ottoman soldiers, who for the remainder of the war were besieged in pockets ranging from Medina down to Yemen. While this made Ottoman Arabia south of Aqaba a 'frozen theater of war' (Pope / Wheal 2003: 353), it had only limited effects on the activities in Mesopotamia and Palestine, at least until the summer of 1918.

By the summer of 1916, the declining performance of the Ottoman transportation network, with its backbone of incomplete and inefficient railways, became particularly worrying. The extension of the Baghdad railway from Ras el Ain in the direction of Mosul was under construction, so a section of the Euphrates had been set up for the makeshift transport of armaments downstream to Baghdad. The greatest difficulties, however, still were caused by the railway gaps in the Taurus and Amanus mountain ranges. Instead of accelerating the closing of these gaps, the work suffered further delay due to the 'deportation' of Armenian railway workers. Thus, inadequate transport services resulted in increasing supply difficulties on all fronts. Even food and clothing could no longer be supplied in needed quantities. This contributed to an increasing rate of desertion. All in all, there were increasing signs that two years into the war the Ottoman Empire suffered a steady and irreversible military and economic exhaustion.

Despite its own shortages, Germany tried to shore up where Ottoman needs were greatest. By autumn 1916, 16 columns of trucks were delivered, a railway engineering company begun working in the Taurus region, and rolling stock was made available. By the end of August 1916, German military personnel serving in the Ottoman army and navy numbered already around 630 officers and 5,900 men (Reichsarchiv 1936: 616).

On the Ottoman-Russian front in eastern Anatolia, unlike in Mesopotamia and Palestine, there was only little German involvement. However, this front most concerned the Ottoman Supreme Command and shaped its strategic decisions as well as the allocation of men and materials. Besides on occasion a small 'visiting' fighting unit, the most sustained German involvement were a few columns of trucks (Reichsarchiv 1936: 609). Thus, no German topographic map series was launched on eastern Anatolia, which was only marginally covered by the north-eastern sheets of "Operationskarte" and "Karte von Mesopotamien (und Syrien)" (see Tables 2 and 4), and reprints of Ottoman and Russian map series.

After the Russian February revolution in 1917, the Russian front in eastern Anatolia rapidly disintegrated and the state collapse in the Caucasus gave the Ottomans the windfall opportunity to regain the pre-war border and beyond that the chance of a Pan-Turkish expansion into the Caucasus ultimately capturing the oil city of Baku on the Caspian Sea. This led, unresolved until the collapse of the Central Powers in October/November 1918, to severe disputes between Berlin and Constantinople over the post-revolutionary war aims. The German Supreme Command saw the main task in focusing on the fight against the British in Mesopotamia and Palestine and otherwise in establishing cooperation with revolutionary Russia to secure oil supplies from Baku for the German war economy (Reichsarchiv 1942: $35)$. 


\section{4}

August

3

Ottoman Empire publicly declares armed neutrality but secretly joins Central Powers

November

$5 \quad$ Britain and France declare war on Ottoman Empire (Russia already on November 3)

$8 \quad$ British capture island Fao in mouth of Shatt el Arab, begin of the Mesopotamia Campaign

22 After Battle of Basra (November 11-12) British capture Basra and thereby close off Ottoman access to Persian Gulf

December

9

British capture Qurna at the confluence of Euphrates and Tigris

1915

January

26

Ottomans invade in January and on that day attack on the Suez Canal. Upon retreat they hold onto line El Arish - Nekhl

April

8

Last of several raids by German aided small Ottoman detachments to disrupt ship traffic on the Suez Canal

$11-14$

25

Ottoman first counterattack in Mesopotamia fails to retake Basra, resulting in Ottoman retreat to Nasiriyah

Dardanelles (Gallipoli) Campaign begins with Allied landings

July

25

British capture Nasiriyah, Ottomans give up southern Mesopotamia and retreat to Kut al-Amara

September

28 British capture Kut al-Amara during sustained progress up Tigris River towards Baghdad

October

14 Bulgaria joins war on side of Central Powers, thereby providing first land link between Germany and Ottoman Empire

November

22-25 Ottomans repel $1^{\text {st }}$ British attack on Baghdad in Battle of Ctesiphon south of the city, British retreat to Kut al-Amara

December

7

British forces are cut off from supply lines to Persian Gulf and besieged in Kut al-Amara

Not attributable to specific month:

Operationskarte, 1:800,000 - Konstantinopel, Konia, Suez

Karte des türkisch-ägyptischen Grenzgebietes, 1:250,000 - 1 Port Said, 2 Rafa, 3 Sues, 4 Akaba

\section{6}

January

9

Dardanelles Campaign ends with defeat and retreat of Allied forces.

April

23

Ottoman-German $2^{\text {nd }}$ attack on the Suez Canal, but stopped at Romani east of the canal and turns into siege of that area

29

June

5

Surrender of besieged British forces (about 13,000 men) in Kut al-Amara

$15-16$

Emir Hussein opens Arab Rebellion against Ottoman rule of the Hedjaz, with British aid soon capture Mecca and Jeddah, subsequently harrassing the Hejaz Railway (Damascus - Amman - Medina - Mecca) and progressing northward

August

4 Secret Sykes-Picot Agreement on Anglo-French territorial distribution of Ottoman Asia

November

13 British begin attack to retake Kut al-Amara as part of $2^{\text {nd }}$ attack on Baghdad

$21 \quad$ British recapture El Arish

Not attributable to specific month:

Operationskarte, 1:800,000 - Beirut

Karte von Mesopotamien (und Syrien), 1:400,000 -2c Der es-Sor ( $1^{\text {st }}$ edition), 3c Ana (1st edition), 4c Samarra (1st $+2 \mathrm{nd}$ editions), 4d Kerbela, 5c

Suleimanije ( $1^{\text {st }}$ edition), $\mathbf{5 d}$ Baghdad

Karte des türkisch-ägyptischen Grenzgebietes, 1:250,000 - 1 Port Said, 2 Rafa, 3 Sues, 4 Akaba 


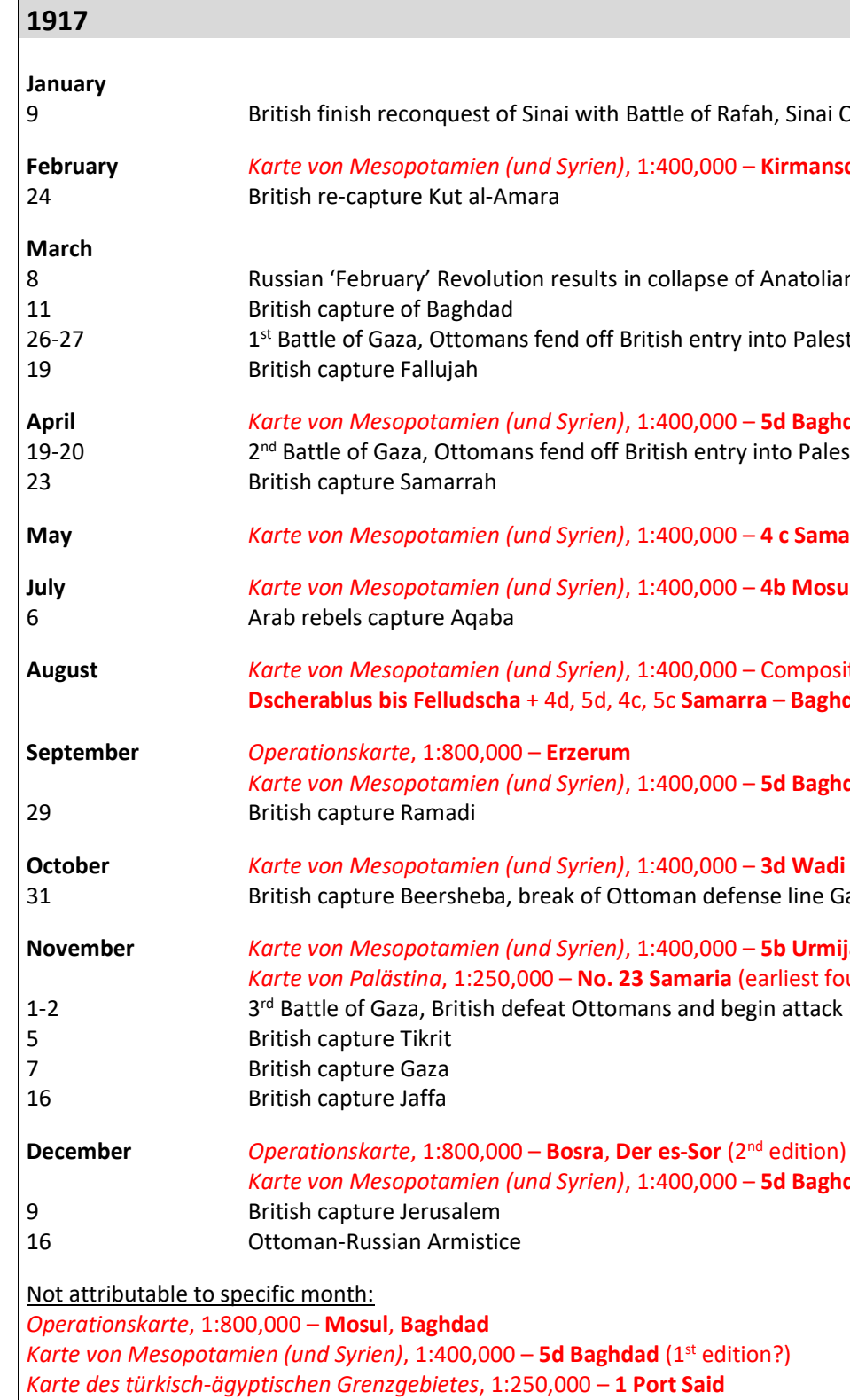

February Karte von Mesopotamien (und Syrien), 1:400,000 - D Damaskus, 3c Ana (2 ${ }^{\text {nd }}$ edition), 4d Kerbela (2 ${ }^{\text {nd }}$ edition) Karte von Palästina, 1:250,000 - No. 70 el Maschatta (two editions in this month), No. 75 ed Dschafar (only found edition), No. 87 Damaskus (earliest found edition) Karte von Palästina, 1:50,000 - No. 60a Ain el Ruwer (earliest found edition), No. 79 Dschenin (only found edition) British capture Jericho 


\begin{tabular}{|c|c|}
\hline 3 & Ottoman Empire joins Central Powers' Peace of Brest-Litowsk with revolutionary Russia, regains 1914 borders and more \\
\hline 23-30 & British extend operations to Trans-Jordan, but Ottoman-German forces fend them off from Amman \\
\hline 28 & British march up Euphrates River stalls until end of war with capture of Anah \\
\hline \multirow[t]{7}{*}{ April } & Karte von Mesopotamien (und Syrien), 1:400,000 - Composite Sheet: Baghdad - Samarra - Kerkuk \\
\hline & Karte von Palästina, 1:250,000 - No. 108 (= 23) Samaria (second edition), No. 57a Hauran (second edition) \\
\hline & Karte von Palästina, 1:100,000 - No. 143 Zusammendruck Tul Kerm - Jericho (earliest found edition) \\
\hline & Karte von Palästina, 1:50,000 - No. 47a Ramleh (earliest found edition), No. 51a Lubban (earliest found edition) + \\
\hline & No. 51b, improved edition, 18.5.1918, No. 52b Tul Kerm (earliest found edition + an improved edition), No. 65c Kalkilje \\
\hline & (earliest found edition), No. 67a Hesban (earliest found edition), No. 71a Nahr Rubin (earliest found edition), \\
\hline & No. 86a es Salt (earliest found edition), No. 127 Bethlehem (only found edition) \\
\hline \multirow[t]{5}{*}{ May } & Karte von Mesopotamien (und Syrien), 1:400,000 - B Adana, C Tarabulus, 1b Aleppo, 1c Hama, 1d Bosra, 3b Mardin \\
\hline & Karte von Palästina, 1:250,000 - No. 108a (= 23) Samaria (third edition), No. 130 Galiläa (only found edition \\
\hline & Karte von Palästina, 1:50,000 - No. 51b Lubban (improved edition), No. 63c ed Damje (earliest found edition), No. 82c \\
\hline & Kaisarje (only found edition), No. 118a -Nazareth (only found edition), No. 126 Jaffa (earliest found edition), No. 128 Bet \\
\hline & Dschibrin,, No. 131 (only found edition), Besan (earliest found edition), No. 139 (= 68), further improved edition) \\
\hline 7 & British temporarily capture Kirkuk, their northernmost progress, then front stalls in the region until the end of war \\
\hline 21 & Ottomans begin invasion in unsettled post-revolutionary southern Caucasus (alliance with Azeris on June 4) \\
\hline June & $\begin{array}{l}\text { Karte von Palästina, 1:50,000 - No. 46b Jericho (improved edition), No. } 149 \text { (= 63) ed Damje (improved edition), No. 65c } \\
\text { Kalkilje (later edition), No. } 67 \text { Tubas (improved edition), No. 86c es Salt (further improved edition), No. 101b Amman } \\
\text { (improved edition), No. } 144 \text { Jerusalem (only found edition), No. } 153 \text { Dschulis (only found edition), No. } 154 \text { Wadi el Hesi } \\
\text { (only found edition) }\end{array}$ \\
\hline \multirow[t]{5}{*}{ July } & Karte von Mesopotamien (und Syrien), 1:400,000 - 5b Urmija ( $2^{\text {nd }}$ edition) \\
\hline & $\begin{array}{l}\text { Karte von Palästina, 1:250,000 - No. 108b (= 23) Samaria (fourth edition), No. 57b Hauran (improved second edition), } \\
\text { No. } 87 \text { a Damaskus (second edition) }\end{array}$ \\
\hline & Karte von Palästina, 1:100,000 - No. 143 Zusammendruck Tul Kerm - Jericho (second edition) \\
\hline & $\begin{array}{l}\text { Karte von Palästina, 1:50,000 - No. 60b Ain el Ruwer (further improved edition), No. } 149(=63) \text { ed Damje (two further } \\
\text { improved edition), No. 65c Kalkilje, further improved edition, No. 76c (= 67) Tubas (further improved edition), No. 69b }\end{array}$ \\
\hline & $\begin{array}{l}\text { Nablus (further improved edition), No. 71a Nahr Rubin (improved edition), No. 102b Kalaat ez Zerka (only found } \\
\text { edition), No. 111a Haifa (only found edition), No. } 126 \text { Jaffa (improved edition), No. } 166 \text { Tiberias (only found edition) }\end{array}$ \\
\hline \multirow[t]{3}{*}{ August } & Karte von Palästina, 1:100,000 - No. 172 Zusammendruck es Salt - Amman (only found edition) \\
\hline & $\begin{array}{l}\text { Karte von Palästina, 1:50,000 - 46b Jericho (further improved edition), No. 76c (= 67) Tubas (improved edition), } \\
\text { No. } 69 \text { b Nablus (improved edition), No. } 86 \text { d es Salt (improved edition), No. 101c Amman (improved edition) }\end{array}$ \\
\hline & Karte von Palästina, 1:25,000 - No. 169 - Wilhelma. 59. S.W. (only found edition), No. ? - Azzun. 59.N.O. (only edition) \\
\hline \multirow[t]{2}{*}{ September } & Karte von Palästina, 1:50,000 - No. 131 Besan (improved edition), No. ? [not printed on sheet] Mkes (only found edition) \\
\hline & $\begin{array}{l}\text { Karte von Palästina, 1:25,000 - No. 174a - Rafat. 59. S.O. (only found edition), No. 176a -Abwen. 60.S.W. (only found } \\
\text { edition), No. } 178 \text { - Sabje. } 59 \text { N.W. (only found edition), No. } 180 \text { - Muannis.58.N. (only found edition) }\end{array}$ \\
\hline 18 & Ottoman-Azeri forces capture Baku, bringing the southern Caucasus under an Ottoman Pan-Turkish alliance \\
\hline $19-25$ & Battle of Megiddo results in collapse of Ottoman defense line in Palestine \\
\hline 20 & British capture Nazareth. Records of Army Group "Yiderim" burned when giving up HQ at Casa Nuova monastery \\
\hline 23 & British capture Haifa \\
\hline 25 & British capture Tiberias and Amman \\
\hline 28 & Arab-British forces capture rail hub Deraa \\
\hline \multicolumn{2}{|l|}{ October } \\
\hline 1 & British capture Damascus, followed by arrival of the Arab rebels on October 3 \\
\hline 2 & British land forces in Beirut \\
\hline 26 & Arab-British forces capture Aleppo \\
\hline 30 & Ottoman Empire accepts armistice on terms of Allied Powers \\
\hline December & Operationskarte, 1:800,000 - Urmija \\
\hline \multicolumn{2}{|c|}{ Not attributable to specific month: } \\
\hline \multicolumn{2}{|c|}{ Karte von Mesopotamien (und Syrien), 1:400,000 - 5c Suleimanije ( $2^{\text {st }}$ edition, August 1917 but printed 1918) } \\
\hline \multicolumn{2}{|c|}{ Karte von Palästina, 1:50,000 - Blatt 90 Ain Dschidi } \\
\hline \multicolumn{2}{|c|}{ Karte von Palästina, 1:25,000 - No. ? [not printed on sheet] - Blatt Jafr. Haris. 60. N.W., } \\
\hline \multicolumn{2}{|l|}{1919} \\
\hline November & Karte von Mesopotamien (und Syrien), 1:400,000 - Kaf \\
\hline
\end{tabular}

Table 1. Synchronoptic timetable on military developments in Ottoman Asia and German topographic map series of the Sinai, Mesopotamia, and Palestine theaters of war 


\section{Introduction to the organization of German military cartography}

The organization of the German Empire's official (military) cartography is rather complicated. Reflecting the Empire's federal structure, the Kingdoms of Prussia, Bavaria, Saxony, and Württemberg during peacetime all maintained separate General Staffs with survey sections, which only during wartime were directed by the Prussian General Staff and its Kartographische Abteilung der Königlich Preußischen Landesaufnahme (= Cartographic Section of the Royal Prussian Survey) (Espenhorst 2016: 90).

With the reciprocal declarations of war in August 1914, the Prussian General Staff took over command of all federated militaries and their survey sections. Since many of the trigonometrical, topographic, and cartographic staff of the Royal Prussian Survey (and the federated surveys) and the General Staff itself left for active duty in the field, the Kartographische Abteilung der Königlich Preußischen Landesaufnahme effectively ceased to function, assuming a soon German victory. All that remained in Berlin was the Stellvertretender Generalstab (= Deputy General Staff) for administrative purposes, most notably organizing the recruitment and training of new units for the fronts. In surveying this was mimicked by Kartographische Abteilung des stellvertretenden Generalstabs (= Cartographic Section of Deputy General Staff), which originally was only a small left behind unit to supply the armies in the field with prints and minor revisions of existing map series (Espenhorst 2016: 92). However, soon the armies were operating in insufficiently or outright uncharted territories and set up their own Vermessungsabteilungen (= Survey Sections) at army staff level, while the Kartographische Abteilung des stellvertretenden Generalstabs took on the limited task to produce map series for such theaters of war without German army survey sections, like for the dispersed small German units in Ottoman Asia and extensively drawing on (captured) enemy maps if not reprinting them in mere translation.

When it had become obvious that the small Kartographische Abteilung des stellvertretenden Generalstabs was unable to fulfill the growing needs for a centralized support of the military demands, the Kartographische Abteilung der Königlich Preußischen Landesaufnahme was reactivated in April 1917 by calling back to Berlin some staff from the fronts. By then, the Vermessungsabteilungen of the field armies had already established the custom to date and add the print of a running number to their often hastily made and rapidly revised maps for easy distinction of the edition succession. By the end of the war, some 10,000 men served at the hub in Berlin and in the numerous army affiliated surveying sections (Espenhorst 2016: 93).

When the First World War broke out, the Ottoman military had only a few map (series) of the soon-to-be combat areas. Often these were not very precise, of too small scale for tactical needs, and severely out of date. The most useful topographic maps at hand for tactical purposes had been created by the regional adversaries Russia for parts of Anatolia and the British in Palestine (see section 5.2). That is why the Germans sent experts with their first auxiliary troops in 1915. In the same year, academic Albert Tafel began to record the Euphrates in Mesopotamia and Africa, while experienced Major Hans von Ramsay undertook route traverses in the Sinai towards the Suez Canal. In addition, small German map units were created in Erzurum and Baghdad in 1916, the latter under archaeologist Walter Andrae (Holzhausen 1937: 167).

To cater for the General Staff's strategic planning beyond the immediate regions of the Western and Eastern Fronts, the Kartographische Abteilung des stellvertretenden Generalstabs in 1914 embarked on compiling the "Operationskarte" (= Operational Map, see Table 2) in the scale 1:800,000. Including a few sheets finished after the armistice in November 1918, by 1920 altogether more than 80 sheets from Ireland's west coast to western Persia had been produced. (Espenhorst 2016: 112-113) With eleven sheets a sizeable number covered the Asian parts of the Ottoman Empire. Ottoman surveys were often based on outdated sheets of foreign pre-war origin. The Kartographische Abteilung des stellvertretenden Generalstabs also started reprinting map series of combat areas in the Ottoman Empire. The first project was the bilingual GermanTurkish reprint of a British map of the Dardanelles (Holzhausen 1937: 167).

The German map series, their sheets, and editions discussed in this paper and listed in the Tables 1-5 are compiled based on the author's personal inspection of original sheets at and, due to Covid 19 closures of map repositories, also through scans made available by

- $\quad$ Staatsbibliothek zu Berlin, Kartensammlung

- Bayrisches Hauptstaatsarchiv, Abteilung Kriegsarchiv

- National Library of Israel, Map Collection

- Library of Congress, Geography \& Map Division

- Deutsches Archäologisches Institut, Abteilung Istanbul 


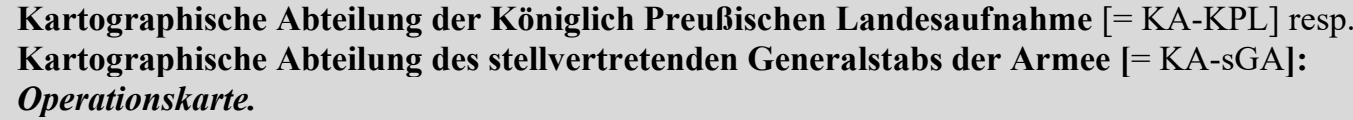

Table 2. Operation Map, classified, lithography. General Staff's strategic planning map of Europe and Near East with 11 Sheets produced on Asian parts of the Ottoman Empire. Production dates: series since 1914, Ottoman Asia 1915-18.

\section{Sinai}

\subsection{Orientation on military operations}

Instead of countering the British landing in southern Mesopotamia (see Table 1 and Section 4.1), the Ottomans since the autumn of 1914 , at the insistence of their German ally, prepared an attack on the Suez Canal, a centerpiece of the British Empire. The first German units to arrive at any Ottoman front in late autumn were railway engineer soldiers to help advance the field railway south to Beersheba and from Gaza along the north coast of the Sinai to logistically prepare the Ottoman attack. In December 1914, a naval medical unit was added to contain infectious diseases, the main threat to all concentration of troops in Asian theaters of war. Long delayed in staging their forces by inadequate supply lines, the Ottomans advanced in mid-January 1915 with around 16,000 men who within ten days crossed the northern Sinai and attacked the Suez Canal on 26.1.-4.2.1915, even briefly crossing to the west bank. Superior British defense, however, forced the Ottomans' main force to retreat to its supply base in southern Palestine, but they were able to keep most of northern Sinai occupied by outposts (Reichsarchiv 1933: 172; Schulz 2012: 89).

In a strategic assessment, Ottomans and Germans at the end of November 1915 concluded that their resources would not allow the fully fledged invasion of Egypt that had been planned in the previous year, but only to attempt a raid-like disruption of shipping traffic on the Suez Canal. On this operational basis, the advance of an Ottoman expeditionary force was scheduled for the spring of 1916, which Germany since mid-January 1916 reinforced with the detachment of mainly special forces to provide the new Ottoman attack on the Sinai and the Suez Canal more thrust. After arduous weeks of making its way to Palestine across the inefficient and in part even unfinished railway line Constantinople - Aleppo Damascus - Jerusalem, the first infantery and special forces arrived. That expeditionary force was sensibly code-named "Pascha" and comprised of about 1,650 men, mostly in artillery, machine gun platoons, a flying squadron, and other special units. The first German units arrived in the southern Palestinian desert at the end of March 1916, but it took until June that the GermanOttoman deployment was, in a makeshift fashion, in place (Reichsarchiv 1936: 610).

In the meantime, the biggest of multiple Ottoman raids in 1915-16 to interrupt ship traffic on the Suez Canal was carried out in April 1916 with around 2,000 men and Arab camel riders as flank protection. They encountered and were fended off by battle-hardened British troops that were transferred from the vacated Gallipoli front in early 1916 and with their experience had built extensive entrenchments on the apron of the east bank of the canal (Schulz 2012: 89; Pope / Wheal 2003: 352). This did not bode well for the major Ottoman attack, which had been delayed to the summer, the hottest and most unfavorable time of year to wage war in the Near East. Despite concerns of the German officers, the Ottoman offensive was unleashed on 4.7.1916 with 18,000 men and as many camels in the supply train. The advance failed, again, to overcome fortified British positions in the battle at the fortified 
waterhole Bir Romani on 3.-5.8.1916 and the Ottomans had to retreat to El Arish by mid-August (Schulz 2012: 90). Thereafter significantly reinforced British forces drove back the Ottomans until the end of 1916 to the (Anglo-)Egyptian-Ottoman border at Rafa, just west of the Palestinian border city Gaza. The front had returned to where the Ottomans had made their first push into the Sinai two years ago in January 1915 (Reichsarchiv 1933: 194).

\subsection{German military map series}

When the war broke out, the best map of the Sinai and Southern Palestine in the hands of the Central Powers was the British General Staff map series in the scale of 1:250,000 in 8 sheets, which was completed in 1909, but as most recent content only included 1906 survey results of Ottoman-Egyptian border from Rafa to Eilat. In the east that map series reached to Petra and in the north just to the border village of Rafa (Fischer 1940: 74-75).

Since Berlin deemed the Suez Canal and Egypt primary strategic targets, preparations for an updated German map series of the same scale became an urgency. To provide military reconnaissance, Major Hans von Ramsay, a tested surveying hand in German colonial service in East Africa and Cameroon, in 1915 undertook route traverses and inquiries in the northern Sinai, which necessarily was the main operation area for the Ottoman attack, in particular regarding the roadways and watering situation. Since von Ramsay was unable to progress his explorations into the British held apron of the Suez Canal, the map in the west shows much less content than in the east (Alt 1920: 99).

The resulting "Karte des Türkisch-Ägyptischen Grenzgebietes (zwischen Hedschas-Bahn und Sues) [...]" (= Map of the Turkish-Egyptian border area [between Hejaz Railway and Suez]) on a scale of $1: 250,000$ in four sheets was compiled and issued by Kartographische Abteilung des stellvertretenden Generalstabs der preußischen Armee based on, according to its title, "route recordings made in 1915 and using the previously known map material" (see Table 3 ). The map series covers the area between the longitudes $32^{\circ}-36^{\circ}$ East and the latitudes $29^{\circ} 25^{\prime}-32^{\circ}$ North. The detailed topographical terrain drawing shows brown form lines but only a few spot heights, while for movement of large military formations no fewer than eleven types of water features are logged. Some identified editions of this map series are geared for field use by German and Ottoman officers and thus are bilingual with Latin (German) and Arabic (Turkish) lettering. Although the first edition of each of the four sheets carry the date ' 1915 ', Alt claims these were only printed in 'early 1916' (Alt 1920: 99).

\section{Kartographische Abteilung des stellvertretenden Generalstabs der preußischen Armee: Karte des türkisch-ägyptischen Grenzgebietes (zwischen Hedschasbahn und Sues) [...] Scale: 1:250,000.}

Blatt 1 (= Port Said) in five editions:

1915, $1^{\text {st }}$ Edition 1916, $1^{\text {st }}$ Edition 1916 - Arabic, $2^{\text {nd }}$ Edition 1916, Edition 1917

Blatt 2 (= Rafa) in four editions:

1915 - bilingual German and Arabic, 1916, $2^{\text {nd }}$ Edition 1916, $2^{\text {nd }}$ Edition 1916 - Arabic

Blatt 3 (= Suez) in three editions:

$1915,1^{\text {st }} \& 2^{\text {nd }}$ Edition 1916, 1916 - Arabic

Blatt 4 (= Aqaba) in three editions:

1915 - bilingual German and Arabic, $1^{\text {st }} \& 2^{\text {nd }}$ Edition 1916,1916 - Arabic

Table 3. Map of the Turkish-Egyptian Border Area (between Hedjaz Railway and Suez), classified, preliminary edition, lithography. 4 sheets. Production dates: 1915-17.

During the Ottoman advances to the Suez Canal in 1915 and 1916, copies of the new edition of the British General Staff map series in the scale of 1:250,000 were captured. These carried extensive updates based on British surveys and water explorations carried out eastwards to Beersheba in Ottoman Palestine in 191314, officially for the Palestine Exploration Fund, in which as archaeologist the young T.E. Lawrence took part, who two years later as British emissary would incite the Arab revolt. These and other captured maps helped to correct later editions of the German map series (Fischer 1940: 75), especially regarding the flat and sandy plains of the north coast of the Sinai and the traffic routes passing through it, which were greatly expanded both by the British and the Ottomans during their respective advances. As on all fronts of the First World War, aerial photographs became an increasingly important source for up-to-date topographical reconnaissance. In that regard, the German map series benefited from Flying Squadron 300, which had been deployed in spring 1916 (Holzhausen 1937: 166). 


\section{Mesopotamia 4.1 Orientation on military operations}

Only a few days after the British declared war on the Ottoman Empire, they started a well-prepared attack on the Ottomans narrow coastal access to the Persian Gulf. On 8.11.1914 mostly colonial Indian forces landed on the fortified island of Fao at the confluence of the Shatt el Arab into the Persian Gulf, meeting such weak resistance that the invasion force captured Basra, the hub of southern Mesopotamia, by November 22. That easy success launched the Mesopotamia Campaign towards Baghdad, which by December 9 had already captured Qurna at the confluence of the Tigris and Euphrates rivers, $250 \mathrm{~km}$ inland from the Gulf coast (Reichsarchiv 1933: 173).

While the Ottomans in the Sinai in 1915 and 1916 launched three major attacks and undertook several small raids on the Suez Canal, in Mesopotamia the British in fall of 1915 had not only repulsed just a single Ottoman attempt in April 1915 to retake Basra (Reichsarchiv 1933: 194), but with reinforcements after the end of the Gallipoli affair continued their steady progress on Baghdad along the rivers Euphrates and Tigris. In September 1915, the British expeditionary forces captured Kut al-Amara on the Tigris, about 200 $\mathrm{km}$ southeast of Baghdad, which they used to stage a surprise dash for Baghdad, which the Ottomans narrowly defended on November 22-25 at the Battle of Ctesiphon on the southern outskirts of the city. The British forces retreated to Kut al-Amara, which Ottomans succeded to besiege in December and fending off British relief attacks. On 29.4.1916, the nearly 13,000 men in Kut al-Amara surrendered, arguably the most humiliating British defeat in the First World War.

The Ottoman defense against the British advance in Mesopotamia received its' first German support at the beginning of 1916: In February, the first German airplanes and pilots arrived alongside largely Germanmaned flotillas on the Euphrates and Tigris to relieve the slow overland supply lines by raid and road (Reichsarchiv 1936: 607). After the debacle at Kut alArma, British forces were reorganized, steadily increasing to the peak of about 250,000 wellprovisioned men by the end of 1917, with half of these in fighting units on the front, and light railway, ship, and road supply lines to the Persian Gulf, by early 1917 . The at no time before or after more than about 50,000 ill equipped Ottoman soldiers were unable to put on even a delaying resistance: The British marched on to capture
Baghdad on March 11 and Samarra on April 23. Thereafter the Ottoman retreat northwards slows, but only because the British relocated many of their troops to the Sinai (Pope / Wheal 2003: 316) to strengthen the forces along the line Gaza - Beersheba for the invasion into Palestine (see Section 5.1). After reaching Anah on the Euphrates River on 28.3.1918 and briefly capturing Kirkuk on May 7, the British again withdrew many fighting units for the September attack in Palestine, to force a decision in the Asian theater by driving the Ottoman-German defenders out of Palestine and Syria.

\subsection{German military map series}

Although many times the size of Palestine, the Mesopotamian plains on both sides of the Euphrates and Tigris Rivers, with its desert fringe southwards to Arabia and the foothills of the Persian mountain ranges to the northeast, must be regarded as the cartographic stepchild of both the Ottomans and the Germans. With an even worse history of surviving German military files and a lack of publications by veterans involved in the German mapping series of Mesopotamia, this paper can offer only a few preliminary remarks.

That fact that reverse sides of test prints as well as issued editions of Mesopotamia sheets, rendered obsolete by the then British advances up Euphrates and Tigris Rivers, were re-used by Vermessungsabteilung 27 due to the scarcity of map paper for printing updated editions of sheets of "Karte von Palästina" (see section 5.2) is an indication that the Survey Section was at least involved if not in charge of drawing and printing the sheets of "Karte von Mesopotamien (und Syrien)" in the scale of 1:400,000 (see Table 4) since its deployment to the Asian theater of war in September 1917. Although Kartographische Abteilung des stellvertretenden Generalstabs der Armee resp. Kartographische Abteilung der Königlich Preußischen Landesaufnahme are printed as issuers on the sheets of this series, this would match with the observation that only five sheets had a single edition each in 1916, but all other sheets and editions (in all 32 editions) relatively match the formation of Vermessungsabteilung 27 in spring 1917 in Berlin, its deployment to Aleppo, Jerusalem, Nazareth and Damascus with the last identified edition (Sheet D. Damaskus, September $1918^{2}$ a tempting fit with the then last days of operation of the Survey Section in the Omayyad city. Another indication are the striking gaps in the numbering sequence printed on the sheets and editions of "Karte von Palästina", especially the many missing numbers up to 50 , which could have

2 The outlier date "November 1919" for sheet 1e Kaf (see Table 4) could be a printing error. 
been assigned internally but not printed on the editions of "Karte von Mesopotamien (und Syrien)" and the related "Karte von Nordbabylonien" in the scale of
1:200,000 (see Table 5), of which so far only two sheet in a single edition could be located.

\section{Kartographische Abteilung der Königlich Preußischen Landesaufnahme [= KA-KPL] resp. Kartographische Abteilung des stellvertretenden Generalstabs der Armee [= KA-sGA]: Karte von Mesopotamien (und Syrien) \\ Scale: 1:400,000.}

B. Adana, May 1918 [KA-KPL]

C. Tarabulus, May 1918 [KA-KPL]

D. Damaskus, February 1918 [re-?]printed September 1918 [KA-KPL]

E. Jerusalem, March 1918 [KA-KPL]

1b. Aleppo, May 1918 [KA-KPL]

1c. Hama, May 1918 [KA-KPL]

1d. Bosra, May 1918 [KA-KPL]

1e. Kaf, November 1919 [sic!] [KA-KPL]

2c. Der es-Sor, 1916 [KA-sGA] + December 1917 [KA-KPL]

3b. Mardin, May 1918 [KA-KPL]

3c. Ana, 1916 [KA-sGA] + February 1918 [KA-KPL] + February 1918 - bilingual German and Arabic [KA-KPL]

3d. Wadi Hauran, October 1917 [KA-KPL]

4a. Wan, October 1917 + January 1918 [KA-KPL]

4b. Mosul, July $1917+$ August 1917 [KA-KPL]

4c. Samarra, $1916+1916$ update of SE quadrant only + May 1917 + October 1917 [KA-sGA]

4d. Kerbela, 1916 [KA-sGA] + February 1918 [KA-KPL]

5b. Urmija, November 1917 + July 1918 [KA-KPL]

5c. Suleimanije, $1916+$ August 1917 but printed in 1918 [KA-sGA]

5d. Baghdad, $1917+$ April 1917 + September 1917 + December 1917 [all KA-sGA]

6c. Kirmanschah, February 1917 [KA-sGA]

Specialty Additions:

Composite extracts from Sheets 1b, 1c, 2c, 3c, 4c, 4d Karte des Euphrat von Dscherablus bis Felludscha, August 1917 [KA-KPL]

Composite print from sheets 4d and 5d with parts of sheets 4c and 5c Samarra - Baghdad - Kerbela, August 1917 [KA-KPL]

Composite print Baghdad - Samarra - Kerkuk, April 1918 [in the field]

Release date 1916 = Sheets 2c Der es-Sor, 3c Ana, 4c Samarra (2 editions), 4d Kerbela, 5c Suleimanije

Release date 1917 = Sheets 2c Der es-Sor, 3d Wadi Hauran, 4a Wan, 4b Mosul, 4c Samarra (2 editions), 5b Urmija, 5d Baghdad (4 editions), 6c

Kirmanschah, Composite of Euphrates River, Composite Samarra-Baghdad-Kerbela

Release date 1918 = Sheets B Adana, C Tarabulus, D Damaskus, E Jerusalem, 1b Aleppo, 1c Hama, 1d Bosra, 3b Mardin, 3c Ana, 4a Wan, 4d

Kerbela, 5b Urmija, 5c Suleimanije, Composite Baghdad-Samarra-Kerkuk

Release date $1919=$ Sheet 1 e Kaf

Table 4. Map of Mesopotamia (and Syria), classified, preliminary edition, lithography. 20 sheets (produced) plus 3 composite sheets. Production dates: 1916-18.

\section{Kartographische Abteilung der Königlich Preußischen Landesaufnahme: \\ Karte von Nordbabylonien. \\ Scale: 1:200,000.}

Blatt 6. Mendeli, January 1918

Blatt 9. Kut el-Amara, January 1918

Table 5. Map of Northern Babylonia, classified, preliminary edition, lithography. 2 sheets (produced). Production dates: 1918.

Finally, Kartographische Abteilung der Königlich Preußischen Landesaufnahme in the summer of 1918, when a retreat of Ottoman-German forces from Mesopotamia and Palestine to Anatolia became a strong possibility, adapted four sheets of the 1:200,000 map series of the Imperial Ottoman Survey on southern Anatolia to complement, for the ongoing retreat of the Ottoman-German forces, in a larger scale, the northern edge of its own map series "Karte von Mesopotamien (and Syrien)" in the scale of 1:400,000. These adapted sheets came with a German legend and lettering in four color lithographic print:

- Ma'asch, September 1918,

- $\quad$ Biredschik, August 1918,

- $\quad$ Adana, July 1918,

- $\quad$ Membidsch, 1918. 


\section{Palestine \\ 5.1 Orientation on military operations}

By early 1917, the Ottoman forces inferiority in Palestine and Mesopotamia became all too evident. The German Supreme Command reacted by considerably reinforcing the German expeditionary forces through relocating more troops from the European western and eastern fronts as well as recruiting new units. Still by June, the Germans assumed that the Ottoman could muster a sustained defense of Mesopotamia and Palestine, but by no means wage a counterattack on both fronts (Reichsarchiv 1942: 420). This view was supported by the fact that on the apron of the border town Gaza the Ottomans twice, on March 26 and April 17 , were able to fend off British attempts to break into Palestine. On the other hand, there was the shameful loss of the Mesopotamian metropolis and caliphate city of Baghdad on 11.3.1917, after which Berlin and Constantinople agreed on a joint operation in Mesopotamia, essentially replicating the 1916 attack on the Suez Canal. For that purpose, a mixed OttomanGerman army group with the telling code name "Yilderim" (= lightning) was formed and placed under German command. The German "Pascha" troops, which were dispatched in 1916, received substantial reinforcements to form "Pascha II", which on 1.10.1917 official was designated as Deutsches Asien-Korps (= German Asia Corps). "Pascha II" was not meant to operate on its own but be embedded in the new Ottoman Army Group F "Yilderim".

With initially three infantry battalions, a ranger battalion, pertaining field artillery, four Flying Squadrons with a total of 65 airplanes and several technical units, "Pascha II" numbered about 4,500 men in total. They included a survey section as had become customary for a German army operating in the field. Many experiences in Ottoman theaters of war had been considered for the composition of the German corps, but inevitably the Ottomans were to provide rail transport, horses, and pack animals, which proved too big of a challenge since those did not suffice for their own armies. Due to the highly mechanized nature of the German special forces, the demands on the transport performance of the railroad increased for the German Asia Corps to a multiple of the needs of Ottoman formations of the same size (Reichsarchiv 1942: 421). ${ }^{3}$ Due to the lack of locomotives and fuel on the railways

\footnotetext{
3 Even before the aggravations in 1917, it took the eight machine rifle groups for "Pascha I" from Berlin to Beersheba 51 days, of which "only" 25 days were driving, but 26 days interruptions with 19 days waiting time alone at the Haidar Pasha railhead on the Asian bank of the Bosporus in
}

and the two rail gaps in the Taurus and Amanus mountains only three of the five "Yilderim" divisions were assembled near Aleppo by the end of September. The movement of the German Asia Corps took place even more slowly. Large parts were still at home in September, others were waiting in Constantinople for further transport (Reichsarchiv 1942: 422). The Ottoman Supreme Command successfully pleaded with their German ally to divert "Yilderim" away from the extensive and poorly supplied Mesopotamian theater to strengthen the more promising defense of the much smaller Palestine theater (Schulz 2012: 90).

As in Mesopotamia after the debacle at Kut al-Amara, the British after the defeat in both Battles of Gaza had reorganized by bringing in more troops and robustly improving backward supply lines. By the end of the long stalemate along the Gaza-Beersheba line iby the end of summer 1917, the Palestine Campaign had swollen to about 95,000 well-provisioned men enjoying command of the skies, facing just 33,000 defenders of the Ottoman-German Army Group "Yilderim" (Pope / Wheal 2003: 353). On 27.10.1917, the British artillery began to fire heavily on Gaza, supported soon by naval forces. On October 31, the British attacked Beersheba, which they captured by night fall. On the night of November 7, the Ottomans had to evacuate Gaza, which in March and April they had successfully defended twice, and during the day had to withdraw the entire front line from between the Mediterranean and the Dead Sea Depression to the north, with great loss of men and material. The constant British pursuit did not allow the front to stabilize again until mid-December, only after the loss of Jaffa, Jerusalem, and Jericho, to north of these three places (Reichsarchiv 1942: 425). After achieving the strategic goal of capturing Jaffa and Jerusalem, the British offensive paused for the winter rains, to reassume cautiously in March 1918 by extending the frontline to rugged Trans-Jordan, an effort to overstretch the vastly outnumbered defenders (Pope / Wheal 2003: 353). This extension of the war zone to Trans-Jordan considerably increased the need for constantly updated tactical mapping on the river's east bank to well into the Arabian desert, while the British continued to build up backward supply lines and further amass troops and equipment for a decisive attack in late summer.

Constantinople. In 1917, it took the infantry battalion 701 out of Pomerania to Nablus in Palestine even 90 days, of which only 27 days were traveling, but 63 days were interruptions, 22 of them at Haidar Pasha, 25 at the Amanus track gap, and 15 in Nazareth (Reichsarchiv 1942: 427). 


\subsection{German military map series}

During the first half of the war until the end of 1916 , Palestine was only a stage for marshalling troops and supplies for the Ottoman (-German) attacks on the Suez Canal. For these staging purposes in the own hinterland, the few existing orientation map (series) sufficed, but this changed drastically when early in 1917 the British pushed the front to the line Gaza-Beersheba. When Deutsches Asien-Korps was conceptualized in spring 1917, as was usual with German armies on the Eastern and Western Fronts, a surveying unit, the newly formed Vermessungsabteilung 27, was added and placed under the command of Dr. Hinrichs, who before the war was active at the Deutsche Orient-Gesellschaft (= German Orient Society) archaeological excavations in Assur (Alt 1920: 99-100), and thus had a good knowledge of the region, its people, and the language.

The Survey Section, which as all units of the German Asia Corps the Kartographische Abteilung der Königlich Preußischen Landesaufnahme had furnished with the booklet "Kurze Militärgeographische Beschreibung von Palästina (= Short Military Geographical Description of Palestine) (Espenhorst 2016: 119), accompanied the German expeditionary corps "Pascha II" on its way out via Constantinople to Aleppo, where it briefly quartered in Turkish barracks in mid-September 1917 and began its cartographic activity. Since the Ottomans at that time considered a counterattack against the rebellious Arabs under Emir Feisal and the British agent Lawrence operating from Aqaba against the Hejaz Railway, Vermessungsabteilung 27 first was tasked to compile supporting map material. This work made little progress due to significant staff shortages caused by illnesses in the unfamiliar Oriental environment, when the Army Group "Yilderim" was definitively assigned to the Gaza Front at the end of September 1917. It was characteristic of the then cartographic situation in Palestine that the pilots of the German Flying Squadrons upon leaving Aleppo could not be given for guidance a map of their destination areas in southern Palestine (Holzhausen 1937: 167).

Even before the other staff of Army Group "Yilderim", Vermessungsabteilung 27 arrived in Jerusalem on 12.10.1917, where they moved into an empty house near the Syrian orphanage in the Bukhara district. The working conditions were bad as local materials lacked to set up offices and kerosene for the lamps after dark. The troops had little hard money and the locals no longer took the Ottoman paper money. In addition, the Ottoman soldiers detailed for the trigonometric field work, mostly captured deserters, usually ran away again after only a short time (Holzhausen 1937: 168). Since the Survey Section arrived in Jerusalem just when the front, which for months had stalled between Gaza and Beersheba, was pushed back, systematic mapping of the theatre of war was out of the question. Instead, provisional sheets of the anticipated new front areas were needed and provided. After the loss of the $3^{\text {rd }}$ Battle of Gaza in early November, Jerusalem had to be evacuated and the Army Group "Yilderim" retreated to the north, now operating in areas that were not cartographically covered. The NE Sheet 2 of "Karte des türkisch-ägyptischen Grenzgebietes" in the scale 1:250,000, which was still in general use for operations on the Palestine front in October 1917, reached only as far north as the line Ramla - Amman, which the retreating Army Group was now approaching quickly. Therefore, in an emergency 36 hour effort, Vermessungsabteilung 27 in midNovember produced 200 copies for staff officers of the Army Group of an single sheet extract map called "Mittel-Palästina", forming a northern connection to the NE sheet of the Sinai map series. This was done from its only copy of the reduced map series in the scale of $1: 168,960$, itself being a 1915 reprint by Kartographische Abteilung des stellvertretenden Generalstabs and a reduced version by the Palestine Exploration Fund of its by then more than a geberation old map series in the scale of 1:63,360. This quick shot saved the day but underscored the pressing need for maps.

With the command of Army Group "Yilderim", the Survey Section moved to Nazareth, where it set up office, workshops, and printing presses on November 13 in an Arab school and the Franciscan monastery. Since the British advance northwards paused, Vermessungsabteilung 27 now had a three month long and relatively undisturbed residency. At the end of November 1917, the revised connection sheet "NordPalästina", again based on the Palestine Exploration Fund map, benefited from corrections taken from a captured copy of the latest edition of the British General Staff's map series on Palestine in the scale of 1:250,000 (Alt 1920: 100; Holzhausen 1937: 168). In midDecember 1917, the two maps "Palästina südlicher Teil (Samaria)" and "Palästina nördlicher Teil (Galilee)" were delivered to the troops, again owing much to the captured British General Staff map series in the scale of $1: 250,000$. Such rehashed overview scale maps based on the old and new British map series satisfied strategic needs, but not on-the-spot tactical orientation for fighting units and the air wings. A large-scale map series was urgently needed (Holzhausen 1937: 170). 
A lucky find came to the aid of Army Group "Yilderim" and its surveyors. Captain Hinrichs, commander of Vermessungsabteilung 27, in Haifa accidently came across the yellowed but complete 26 sheets of the Palestine Exploration Fund's semi-official British "Map of Palestine" in the scale of 1:63.360. A field-check showed that the surveys on which the map was based were four decades old and outdated as for settlements and communication lines ${ }^{4}$, but the terrain measurements for the most part were accurate. This chance find by means of photography became the topographic basis for the launch of the large-scale tactical German map series "Karte von Palestina" (= Map of Palestine) in the scale of 1:50,000. After the first sheets had been delivered almost unretouched in mid-January 1918, the entire front line was covered by mid-February 1918. Later editions of the first sheets, as well as the sheets that were added later in 1918, were increasingly based on original field surveys by Vermessungsabteilung 27 and photogrammetric interpretation of aerial pictures supplied by the six Flying Squadrons (Holzhausen 1937: 170).

After the frontline had consolidated by the end of 1917 in southern Palestine, Vermessungsabteilung 27 systematically surveyed the back areas by extensive triangulation networks and filled them with tachymetric surveys of terrain and paths. By redrawing of the older British semi-official Palestine Exploration Fund in the scale 1:63.360 and interpreting aerial photographs made by German flying squadrons, a German war map series was created between February and September 1918 on a scale of 1:50,000 in 40 sheets, which in part went through the issuing of five revised editions (see Table 6). To complement the main series with a more detailed terrain representation of areas close to the front line, in August and September 1918 the Survey Section issued 7 sheets in the scale of 1:25,000, which were based on plane tabeling and thus showed real isohypses instead of the otherwise unavoidable form lines. The advances made, compared to the older British map series, lay mainly in the updated and more precise representation of the settlements and traffic routes as well as the bends of the lower Jordan River and the shores of the Dead Sea. In addition to these map series produced in the field by Vermessungsabteilung 27, Kartographische Abteilung der Königlich Preußischen Landesaufnahme in Berlin published revisions of the reduced scale print of the Palestine Exploration Fund, such as the 1917

\footnotetext{
4 The Palestine Exploration Fund's "Map of Western Palestine" on a scale of 1: 63,360 in 26 sheets was based on surveys carried out in 1872-77, which were not kept up to date after the publication in 1880. Since soon after the publication there was a mushrooming of Jewish and Christian European
}

"Karte von Mittelpalastina" (= Map of Central Palestine) and "Karte von Mitteljudäa" (= Map of Central Judaea), both on the original scale of $1: 168,960$ (Fischer 1940: 76).

Since the Survey Section in Nazareth was based relatively far behind the stalemate front, advanced field map units had to be set up for rapid trigonometric and topographical terrain reconnaissance in close liaison with major detachments of Army Group. By the end of November 1917, two units were established in Nablus and Tulkarm, followed in January 1918 by Jericho, which later moved across the Jordan River to Al-Salt. The work at Vermessungsabteilung 27 was organized into four task groups:

- Trigonometers and topographers for trigonometric and topographic surveys in the field as well as for measuring just behind the frontline the firing targets for the artillery,

- Translators for correct identification and translation of place names,

- Geologists for the search and evaluation of water, a crucial task in arid Palestine and East Jordan,

- Photogrammetrists for the interpretation of the steady inflow of aerial photographs supplied by initially six Flying Squadrons.

In view of the great demands on the Survey Section, its staff was increased several times, reaching a peak in the summer of 1918 with 5 officers and around 160 men. The latter included 16 volunteers from the Württemberg Templar settler colonies in central Palestine, who were of great advantage for the map work due to their knowledge of the country and language (Holzhausen 1937: 171). To update the map representation of the areas on the other side of the front, Vermessungsabteilung 27 relied on captured maps and aerial photos from the German air squadrons of Army Group "Yilderim", which were processed including the use of photogrammetry. This enabled in rapid succession the issuing of sheets, which increasingly were updated and enriched by the incorporation of new field observation and aerial material. Within weeks it was possible to create a provisional map series that met military needs (Alt 1920: 101). The transcription of Arabic names and designations into the Latin alphabet proved to be particularly difficult,

settlement with significant construction of roads and railways and the display of terrain was partly superficial, the British map hardly met modern military tactical needs (Fischer 1940: 77). 


\section{Vermessungsabteilung 27: \\ Karte von Palästina. ${ }^{5}$ \\ Scales: $1: 100,000,1: 50,000$, and $1: 25,000(+1: 250,000)$}

a) Scale: 1:100,000.

Classified, Lithography, 2 Sheets (produced). Production dates: 1918.

No. 143a Zusammendruck Tul Kerm-Jericho, 27.4.1918 + 16.7.1918 [= reduced combined print of 50,000 sheets 50-52 \& 57-61 \& 67-70]

No. 172 Zusammendruck es Salt-Amman, 27.8.1918 [= reduced combined print of 50,000 sheets 61-63 \& 70-72]

\section{b )Scale: 1:50,000.}

Classified, Lithography, $29+11^{6}$ Sheets (produced). Production dates: 1918.

No. 44a - Blatt 69 Jerusalem, 28.3.1918

No. 46b - Blatt 70 Jericho, 16.3.1918 + No. 140a - Blatt 70, $2^{\text {nd }}$ improved edition, 23.6.1918 + No. 140b, $3^{\text {rd }}$ improved edition, 1.8 .1918

No. 47a - Blatt 68 Ramleh, 5.4.1918 + No. 139 - Blatt 68, $3^{\text {rd }}$ improved edition, 17.5.1918

No. 51a - Blatt 60 Lubban, 18.4.1918 + No. 51b, improved edition, 18.5.1918

No. 52b - Blatt 50 Tul Kerm, 9.4.1918 + No. 52c, $4^{\text {th }}$ improved edition, 30.4 .1918

No. 60a - Blatt 80 Ain el Ruwer, 9.2.1918 + No. 60b, $3^{\text {rd }}$ improved edition, 9.7.1918

No. 63c - Blatt 61 ed Damje, $1.5 .1918+$ No. $149-$ Blatt 61, $2^{\text {nd }}$ improved edition, $21.6 .1918+$ No. 149a, $3^{\text {nd }}$ improved edition + No. 149a, $4^{\text {th }}$ improved edition, 31.7.1918

No. 65c - Blatt 59 Kalkilje, revised edition, 21.4.1918 + No. 65c, 17.6.1918 + No. 65c, $7^{\text {th }}$ improved edition, 13.7 .1918

No. 67 - Blatt 52 Tubas, 19.1.1918 + No. 67b, 19.6.1918

No. 67a - Blatt 71 Hesban, 10.4.1918 + No. 76c - Blatt 71, $4^{\text {th }}$ improved edition, 10.7.1918 + No. 76d, $5^{\text {th }}$ improved edition, 2.8 .1918

No. 69a - Blatt 51 Nablus, $25.3 .1918+$ No. 69b, $3^{\text {rd }}$ improved edition, $25.7 .1918+$ No. 69d, $4^{\text {th }}$ improved edition, 27.8 .1918

No. 71a - Blatt 67 Nahr Rubin,19.4.1918 + No. 71b, $2^{\text {nd }}$ improved edition, 10.7.1918

No. 76 see under No. 67 a

No. 79 - Blatt 43 Dschenin, 15.2.1918

No. 82c - Blatt 42 Kaisarje, 5.5.1918

No. 86a - Blatt 62 es Salt, 8.4.1918 + No. 86c, $4^{\text {th }}$ improved edition, $26.6 .1918+$ No. 86d, $5^{\text {th }}$ improved edition, 5.8 .1918

No. 101 - Blatt 72 Amman, 19.3.1918 + No. 101b, $2^{\text {nd }}$ improved edition, 24.6.1918 + No. 101c, $3^{\text {rd }}$ improved edition, 27.8 .1918

No. 102b - Blatt 63 Kalaat ez Zerka, $2^{\text {nd }}$ improved edition, 10.7.1918

No. 111a - Blatt 34 Haifa, improved edition, 11.7.1918

No. 118a - Blatt Nazareth, 23.5.1918

No. 126 - Blatt 58 Jaffa, 1.5.1918 + No. 126a, $2^{\text {nd }}$ improved edition, 6.7.1918

No. 127 - Blatt 79 Bethlehem, 30.4.1918

No. 128 - Blatt 78 Bet Dschibrin, 1.5,1918

No. 131 - Blatt 44 Besan, 7.5.1918 + No. 131, improved edition, 1.9.1918

No. 139 see under No. 47

No. 140 see under No. 46

No. 144 - Blatt 69 Jerusalem, 2nd improved edition, 12.6 .1918

No. 149 see under No. 63

No. 153 - Blatt 77 Dschulis, 14.6.1918

No. 154 - Blatt 76 Wadi el Hesi, 25.6.1918

No. 166 - Blatt 36 Tiberias, 25.7.1918

No. 168 - Blatt 90 Ain Dschidi, ???.1918

No. ? [not printed on sheet] - Blatt 37 Mkes, 2.9.1918

c) Scale: $1: 25,000$.

Classified, Lithography, 7 Sheets (produced). Production dates: 1918.

No. 169 - Blatt Wilhelma. 59. S.W., 12.8 .1918

No. 174a - Blatt Rafat. 59. S.O., $1^{\text {st }}$ improved edition, 15.9.1918

No. 176 ${ }^{\text {a }}$ - Blatt Abwen. 60.S.W., $1^{\text {st }}$ improved edition, 15.9.1918

No. 178a - Blatt Sabje. 59 N.W., $1^{\text {st }}$ improved edition, 15.9.1918

No. 180 - Blatt Muannis. 58.N., 8.9.1918

No. ? [not printed on sheet] - Blatt Azzun. 59. N.O., 18.8 .1918

No. ? [not printed on sheet] - Blatt Jafr. Haris. 60. N.W., ???.1918

Table 6. Map of Palestine, in the scales of 1:100,000, 1:50,000, and 1:25,000.

\footnotetext{
${ }^{5}$ The edition sequences of the 1:50,000 and 1:25,000 map series are obviously incomplete (as likely is the series 1:100,000).

${ }^{6}$ These eleven sheets have been located as low-resolution images only, which did not allow for an appraisal, including the verification of production numbers, editions, and dates. These sheets are Blatt 38 el Mzerib, 39 Chirbet el Razale, 45 et Tajibe, 46 Deraa, 47 Schize, 48 Bosra, 53 Adschlun, 54 Dscherasch, 55 el Mefrak, 64 el Hallabat, 81 Madeba. The author asks readers to communicate carto-bibliographic details about any of these sheets for a future revision of this guide to the discussed German map series.
} 
further complicated by the demand that the result had to be equally understandable for the inexperienced tongues of German soldiers as well as for the ears of the Arabs they encountered in the field.

In mid-February 1918, Vermessungsabteilung 27 was withdrawn to Damascus. As a footprint within the headquarters of Army Group "Yilderim" it left a newly formed fourth field map unit in Nazareth, especially to ensure close working with the command of the Flying Squadrons. In Damascus, the Survey Section had its last longer residency - seven months - during its just a yearlong mission run. In the Syrian metropolis it moved into the Imperial Stables on Djemal Pascha Boulevard, where two newly arrived high-speed printing presses were installed, which significantly increased the output of the sheet copies. As already in Nazareth, Vermessungsabteilung 27 printed and likely kept current - on behalf of the original compiler (?) Kartographische Abteilung des stellvertretenden Generalstabs resp. Kartographische Abteilung der Königlich Preußischen Landesaufnahme - the map sheets of "Karte von Mesopotamien (und Syrien)" in the scale of 1:400,000 for the neighboring theater of war (see Section 4.2 and Table 4). For that purpose, at times a representative of the $6^{\text {th }}$ Ottoman Army, which operated in Mesopotamia, was detached to Damascus. According to Holzhausen, Vermessungsabteilung 27 in Damascus thus was the "center of all cartographic work in the Middle East war zone" (Holzhausen 1937: 172).
On the orders by Army Group "Yilderim", in summer of 1918 an offshoot of the established map series was issued in the scale of 1:100,000 (see Table 5), being reduced from the original sheets in the scale of 1:50,000. Because of its handiness and clear terrain presentation, these mid-scale map sheets quickly became the preferred orientation map, especially among pilots. In the other scale direction, already in the spring of 1918 , preparatory work for a plane table series in the scale of $1: 25,000$ had begun, but progressed slowly in the summer heat, high leaves due to high numbers of sick leave, and handicapped by hostile Arabs. Nevertheless, by September 1918, 7 of the detailed and due to isohypses instead of form lines had been completed (see Table 6). The stock taking by this paper, unfortunately restricted by closures of cartographic holdings due to Covid 19, identifies provisionally the following first and last dated editions:

Map Series 1:250,000

No. 23 Samaria, 1.12.1917 / No. 87 Damaskus, 19.7.1918

Map Series 1:100,000

No. 143 Tul Kerm-Jericho, 27.4.1918 / No. 172 es SaltAman, 27.8.1918

Map Series 1:50,000

No. Tubas, 19.1.1918 / No.? Mkes - 2.9.1918

Map Series 1:25:000

No. 169 Wilhelma. 59 S.W. - 12.8.1918 / No. ? Azzun. 69 N.O. -18.8 .1918$

\section{Vermessungsabteilung 27: \\ No series title printed on these map sheets.}

Scale: 1:250,000. ${ }^{7}$

Classified, Photolithography, 7 Sheets (produced). Production dates: 1917-1918.

No. 23 Samaria, 1.12.1917 + No. 108, 15.4.1918 + No. 108a, 29.5.1918 + No. 108b, 17.7.1918

No. 57 Hauran, 31.1.1918 + No. 57a, 3.4.1918 + No. 57b, improved 2nd edition, 16.7.1918

No. 70 el Maschatta, 1.2.1918+4.2.1918

No. 75 ed Dschafar, 10.2.1918

No. 87 Damaskus, 27.2.1918 + No. 87a Damaskus 19.7.1918

No. 100 Hermon, 20.3.1918

No. 130 Galiläa, 6.5 .1918

No. 108 see under No. 23

Table 7. Untitled map series in the scale of 1:250,000, closely related to the series Map of Palestine (see Table 6).

From the summer of 1918, supplies arriving in Damascus dwindled to such a degree that the operations of the Survey Section suffered considerably. The always limited railway operations shut down even further due to the lack of firewood and rolling stock, deliveries of map paper from Germany were suspended. The remedy was to print on the back of obsolete (Mesopotamian) map sheets of areas now far beyond the actual front lines, but these too were quickly used up (Holzhausen 1937: 172).

\footnotetext{
7 The 1:250,000 map series, although begun earlier than "Karte von Palästina" and extending further north and east, is closely related and the cartography of Palestine sheets are mostly based on pertaining larger scale sheets of "Karte von Palästina".
} 
According to Holzhausen, the maps of the areas east of the Jordan were based - in addition to the aerial photographs - mainly on the use of "Operationskarte" in the scale of $1: 800,000$, the 1907 Hejaz map in the scale of 1:300,000 by the Viennese orientalist Alois Musil, cartographic surveys of longtime Haifa resident Gottlieb Schumacher as well as survey maps compiled for the Hedjaz railway under the supervision of its project manager, Heinrich Meißner Pasha (Holzhausen 1937: 170-171). The Ottoman Land Survey contributed a few single sheet maps to the war effort, including a map of Jerusalem in the scale of 1:200,000, which also contains the entire Dead Sea (Fischer 1940: 77).

The collapse of the Palestine Front in mid-September 1918 brought the Survey Section's operations to an abrupt end. At this point in time, sheets of the even more extensively planned series in the scale of 1:50,000 were available across the Holy Land between the Mediterranean coast and the Arabian desert east of the Hedjaz railway and from south of Bethlehem to north of Nazareth. In terms of content, this map series meant, despite that substantial data was taken over from previous maps and map series, especially the map series of the Palestine Exploration Fund, still a significant step into the modern age both in terms of working methods (aerial photographs, photogrammetry) and content (accuracy of terrain representation, updating of settlements and traffic lines). As for terrain rendering, the meandering course of the River Jordan and the arid mountainous country to its east received a truthful representation for the first time (Alt 1920: 102).

\section{Collapse in September 1918 and loss of cartographic files}

In mid-September 1918, ten Ottoman divisions with a total strength of 20,000 rifles stood in the expansive front from the Mediterranean across the Jordan and into the Trans-Jordan desert. These men were stretched much too thin and far between, matching the combat ability of a much smaller force. The remaining cavalry numbered only about 1,000 sabers. Of the six German battalions, three each stood east of the railroad and east of the Jordan; after losses from combat and disease, only about 2,500 men were left with just a handful of operational aircrafts (Reichsarchiv 1942: 438).

In the early morning hours of 19.9.1918, the final British attack broke out with artillery barrage in the coastal area. Without encountering serious resistance, the British infantry, supported by numerous airplanes, in what is often termed the Battle of Megiddo, pushed through the front. The British cavalry found its way north and northeast open. Less than 24 hours later, on daybreak of
September 20, the headquarters of Army Group "Yilderim" in Nazareth was attacked by British cavalry. It was repulsed, but the appearance of enemy troops 80 kilometers behind the front marked the severity of Ottoman-German defeat, long foreshadowed by hemorrhaging from the breakdown of (unpaid) civil service, shortages in all supplies, low morale, and desertions (Reichsarchiv 1942: 439; Pope / Wheal 2003: $354)$. The mountain roads and paths on both sides of the Jordan were blocked by artillery and columns of vehicles fallen victim to enemy air raids. "Yilderim" lost almost all its artillery in the week following the British first shot. With the disintegration of the OttomanGerman units, the hostile attitude of the Arab population increased, which molested split-off retreating splinter sections (Reichsarchiv 1942: 440).

It was only after the British paused their push forward to establish supply lines through the more than $300 \mathrm{~km}$ of land gain that the Army Group "Yilderim" managed to collect its remains near Aleppo in northern Syria, including less than 2,000 German soldiers, to attempt a last-ditch defensive position. On October 25, BritishArab forces began to advance again on Aleppo. On October 30, the Ottoman Empire signed an armistice with the Entente Powers, which came into effect the following day. Its regulations provided for the about 25,000 German military personnel and civilians still in the country to be deported to their homeland (Reichsarchiv 1942: 441-442).

During the hasty retreat of the German "Yilderim" units, the advanced field map units of Vermessungsabteilung 27 in Nazareth, Nablus, Tulkarm and Al-Salt escaped complete capture only by joining the scrape like Ottoman-German retreat but lost most of their survey notes and cartographic materials. At the same time, German troops in Damascus formed a detachment to march south into Deraa to stop at this junction of the Hedjaz and Palestine railways the advancing Arabs under Emir Feisal. Captain Hinrichs of the Survey Section took command, joined by volunteers from the head office of Vermessungsabteilung 27. Only 27 noncommissioned officers and men were left behind in Damascus to prepare the section's relocation of facilities and materials to the north. After the remnants of the four field map units - 32 men were lost - managed to get through to Captain Hinrichs in Deraa, on September 27 he marched the detachment back, which had swollen to 500 German soldiers mostly separated from their units (Holzhausen 1937: 174), to an already rebellious Damascus. 
The left behind skeleton staff of Vermessungsabteilung 27 meanwhile had moved to Aleppo into a half-ruined caravansary in the middle of the bazaar and even managed to set up a makeshift office with printing machines. But soon after the reunification with its staff returning with Captain Hinrichs, the Survey Section was relocated, again, in October, this time to Bosanti on the northern slopes of the Taurus Mountain, where remnants of Army Group "Yilderim" took the last stand, too. After the Ottomans signed the armistice on October 30, along with other German units the surviving personnel of Vermessungsabteilung 27 was brought to Constantinople early in November. After an internment there for three months, the survey section embarked a German steamer on 29.1.1919 for home (Holzhausen 1937: 175).

The field notes, files, cartographic drafts, and printed output which Vermessungsabteilung 27 produced during its less than a year of activity were lost, first, during the fleeing retreat from Nazareth in September and October 1918, then by the repatriation in early 1919 (Alt 1920: 103). Whatever material had survived, later was transferred to the National Archives in Potsdam. Along with the files of Preußische Landesaufnahme, which unfortunately had not been evacuated, they became a complete loss on 14.4.1945 when the archives burned during an Allied air raid. The military developments outlined in this paper on the Ottoman fronts of the Sinai, Mesopotamia, and Palestine are testimony that no modern war can be waged without detailed and kept current maps, but also that even the best map series cannot win a war.

\section{References}

Alt, A. 1920. Aus der Kriegsarbeit der deutschen Wissenschaft in Palästina. In: Zeitschrift des Deutschen Palästina-Vereins, Band 43, Heft 3-4, pp. 93-108.

Espenhorst, J. 2016. A Good Map Is Half the Battle! The Military Cartography of the Central Powers in World War I. In: Elri Liebenberg / Imre Josef Demhardt / Soetkin Vervust (eds.): History of Military Cartography. Cham et al. (Springer), pp. 83-130.

Fischer, H. 1940. Geschichte der Kartographie von Palästina (Fortsetzung und Schluß). In: Zeitschrift des Deutschen Palästina-Vereins, Band 63, Heft 1-2, pp. 1111.

Goering, W. 1925. Begleitworte zur Übersichtskarte von Palästina. In: Hundert deutsche Fliegerbilder aus Palästina (ed.: Gustaf Dalman), Gütersloh, pp. 23-124.
Holzhausen, R. 1937. Die Tätigkeit der Vermessungsabteilung 27 in Palästina. In: Mitteilungen des Reichsamts für Landesaufnahme (1937: 13), Berlin, pp. 166-175.

Pope, S. / Wheal, E.-A. 2003. Dictionary of the First World War. Barnsley, UK (Pen \& Sword).

Reichsarchiv. 1933. Der Weltkrieg 1914-18. Neunter Band: Die Operationen des Jahres 1915. [...] Berlin. E.S. Mittler \& Sohn.

Reichsarchiv. 1936. Der Weltkrieg 1914-18. Zehnter Band: Die Operationen des Jahres 1916 bis zum Wechsel in der Obersten Heeresleitung. Berlin. E.S. Mittler \& Sohn.

Reichsarchiv. 1942. Der Weltkrieg 1914-18. Dreizehnter Band: Die Kriegführung im Sommer und Herbst 1917. Die Ereignisse außerhalb der Westfront bis November 1918. Berlin. E.S. Mittler \& Sohn.

Schulz, G.M. 2012. Der Einsatz und die Erfolge der Fliegerabteilung 304b in Palästina. In: Blätter zur Geschichte der Deutschen Luft- und Raumfahrt, Heft XIX, pp. 89-93. 